\title{
CDCP1 wt Allele
}

National Cancer Institute

\section{Source}

National Cancer Institute. CDCP1 wt Allele. NCI Thesaurus. Code C95587.

Human CDCP1 wild-type allele is located in the vicinity of 3p21.31 and is approximately 64 $\mathrm{kb}$ in length. This allele, which encodes CUB domain-containing protein 1, may be involved in both cell adhesion and cell-matrix interactions. 